\title{
EWA BAGIŃSKA
}

https://doi.org/10.33995/wu2019.3.1

\section{Wpływ klauzul generalnych na proces zawierania umowy ubezpieczenia w świetle ustawy o dystrybucji ubezpieczeń}

W artykule omówiono zasady oceny postępowania dystrybutorów ubezpieczeń przewidziane w nowym systemie dystrybucji ubezpieczeń, wdrażajacym IDD. Autorka analizuje treść kryteriów uczciwości, rzetelności i profesjonalizmu, a także kryterium obowiqzzu działania w najlepszym interesie klienta. Według autorki odpowiednia propozycja umowy ubezpieczenia powinna zawsze wynikać z uczciwego, rzetelnego i profesjonalnego zachowania dystrybutora. Powyższe kryteria zasadniczo pokrywaja się z klauzulami dobrej wiary, dobrych obyczajów i należytej staranności dłużnika w prawie zobowiqzań. Pomimo szczegółowej regulacji procesu zawierania umów ubezpieczenia, wynagradzania dystrybutorów i konfliktu interesów klauzule ogólne nadal będq odgrywały istotnq rolę. W szczególności klauzula działania w najlepiej pojętym interesie klienta znacznie poszerzyła zakres obowiqzków agenta i multiagentów wobec swoich klientów.

Słowa kluczowe: dystrybucja ubezpieczeń, multiagent, broker ubezpieczeniowy, najlepszy interes klienta, klauzule generalne, postępowanie zawodowe.

\section{Wprowadzenie}

W myśl art. 7 ust. 1 ustawy o dystrybucji ubezpieczeń (dalej: u.d.u.] ${ }^{1}$ dystrybutor ubezpieczeń, wykonujac dystrybucję ubezpieczeń, powinien postępować uczciwie, rzetelnie i profesjonalnie, zgodnie z najlepiej pojętym interesem klientów. Ponadto proponowana przez niego umowa ubezpieczenia lub gwarancji ubezpieczeniowej powinna być zgodna z wymaganiami i potrzebami klienta w zakresie ochrony ubezpieczeniowej lub ochrony gwarancyjnej (art. 8 ust. 3 u.d.u.). Pierwszy

1. Ustawa o dystrybucji ubezpieczeń z 15 grudnia 2017 r. (Dz. U. 2017, poz. 2486) tekst jedn. z 25 października 2018 r. (Dz. U. 2018, poz. 2210; zm. Dz. U. 2018, poz. 2243. 
z przywołanych przepisów stanowi implementację art. 17 dyrektywy nr 2016/97 z 20 stycznia 2016 roku w sprawie dystrybucji ubezpieczeń (dalej IDD)² i jest uszczegółowiony w dalszych przepisach tych aktów prawnych. Natomiast art. 8 ust. 3 u.d.u. wdraża art. 20 IDD. Z kolei art. 18 u.d.u. głosi, że działalność agencyjna powinna być wykonywana z zachowaniem staranności określonej w art. 355 § 2 k.c. oraz dobrych obyczajów.

Z uwagi na wielość kryteriów ogólnych, do których odwołuje się nowa ustawa, powstaje pytanie o znaczenie i rozmiar zmiany normatywnej. W związku z tym, że mamy tu do czynienia zarówno ze stosunkami zobowiązaniowymi leżącymi u podstaw działania dystrybutorów ubezpieczeń, jak i z nawiązywaniem przez nich umów ubezpieczenia lub umów gwarancji ubezpieczeniowej, warto „przełożyć” ustawowe kryteria oceny postępowania dystrybutora na język kodeksu cywilnego. Pomoże to określić relacje między u.d.u. a zasadami zawierania umów na gruncie k.c.

W szczególności można zastanawiać się, czy stawiana w środowisku praktyki ubezpieczeniowej teza o rewolucyjnym charakterze zmian wprowadzonych przez u.d.u. oznacza rzeczywistą rewolucję w procesie zawierania umowy ubezpieczenia. Czy może raczej jest to powtórzenie i uszczegółowienie ogólnych zasad (klauzul) znanych prawu zobowiązań? Celem niniejszego artykułu jest próba znalezienia odpowiedzi na powyższe pytania.

\section{Geneza, nazewnictwo i charakter wybranych klauzul generalnych i kryteriów ogólnych}

Przed przejściem do zasadniczej części rozważań zwróćmy uwagę na dwie kwestie wstępne. Po pierwsze, warto spojrzeć na brzmienie źródłowego art. 17 ust. 1 IDD w trzech głównych językach: angielskim, niemieckim i francuskim. Pewne niuanse językowe unaoczniają bowiem niewielkie odmienności w stosunku do oficjalnej polskiej wersji IDD, co może przekładać się na sposób wykładni art. $?$ u.d.u. W wersji angielskiej art. 17 IDD wymaga zapewnienia przez państwa członkowskie, „aby dystrybutorzy ubezpieczeń, prowadząc dystrybucję ubezpieczeń, postępowali zawsze uczciwie, sprawiedliwie (fairly) i profesjonalnie, zgodnie z najlepszym interesem swoich klientów”3. Niemal identycznie brzmi wersja niemiecka ${ }^{4}$. Wersja francuskojęzyczna dyrektywy głosi, że „Państwa członkowskie zapewniają, aby dystrybutorzy produktów ubezpieczeniowych, prowadząc działalność w zakresie dystrybucji ubezpieczeń, działali zawsze uczciwie, bezstronnie (impartiale) i profesjonalnie oraz w najlepszym interesie swoich klientów ${ }^{5}$. Oficjalne polskie

2. Dyrektywa Parlamentu Europejskiego i Rady (UE) 2016/97 z 20 stycznia 2016 r. w sprawie dystrybucji ubezpieczeń (wersja przekształcona). Tekst mający znaczenie dla EOG, 0J L 26, 2.2.2016, p. 19-59, ELI: http:// data.europa.eu/eli/dir/2016/97/oj [dostęp: 2.11.2019].

3. Member States shall ensure that, when carrying out insurance distribution, insurance distributors always act honestly, fairly and professionally in accordance with the best interests of their customers.

4. Die Mitgliedstaaten stellen sicher, dass Versicherungsvertreiber bei ihrer Versicherungsvertriebstätigkeit gegenüber ihren Kunden stets ehrlich, redlich und professionell in deren bestmöglichem Interesse handeln.

5. Les États membres veillent à ce que, lorsqu'ils exercent une activité de distribution d'assurances, les distributeurs de produits d'assurance agissent toujours de manière honnête, impartiale et professionnelle, et ce au mieux des intérêts de leurs clients. 
tłumaczenie art. 17 IDD $^{6}$ zostało przeniesione do cytowanego na początku art. 7 ust. 1 u.d.u. Zwraca uwagę fakt, że przysłówek „bezstronnie” / „sprawiedliwie” (fairly, impartiale) został przetłumaczony jako „rzetelnie”. Powstaje zatem pytanie, czy mamy do czynienia z faktycznie odmiennym kryterium oceny zachowania dystrybutora w świetle prawa unijnego i polskiego.

Po drugie, należy przypomnieć, że klauzule generalne, które otwierają system prawa na kryteria ocenne pozaprawne, w szczególności na oceny moralne, funkcjonuja powszechnie na świecie pod różnymi postaciami i są nieodłącznym elementem współczesnego prawa cywilnego? W prawie umów spotykamy takie klauzule, jak dobre obyczaje, dobra wiara, słuszność, czy venire contra factum proprium ${ }^{8}$. Ustawodawca zazwyczaj ogranicza się do podania ogólnej zasady (klauzuli), natomiast bliższe określenie stanu faktycznego i skutków prawnych należy do sędziego ${ }^{9}$.

Relacje między wskazanymi klauzulami generalnymi nie zawsze sajasne ${ }^{10}$. Dla przykładu, można się zastanawiać, czym różni się klauzula dobrej wiary od klauzuli dobrych obyczajów, do której odsyła m.in. art. 18 u.d.u., nakazujący agentowi postępować zgodnie z dobrymi obyczajami. Według Adama Szpunara, są to dwie odrębne klauzule, a zasadnicza różnica polega tym, że dobre obyczaje chronią interes powszechny, a dobra wiara interes indywidualny ${ }^{11}$. Z kolei zdaniem Romana Longchamps de Beriera dobra wiara w obiektywnym znaczeniu oznacza to samo, co dobre obyczaje, tj. pewną obiektywna miarę dla oceny czyjegoś zachowania jako odpowiedniego lub nieodpowiedniego z punktu widzenia norm etycznych przyjętych w obrocie ${ }^{12}$. Podobna funkcję spełnia klauzula venire contra factum proprium nemini licet (conceditur), oznaczająca, że podmiot prawa nie może działać przeciwnie do swoich wcześniejszych wyraźnych lub domniemanych oświadczeń, które osobiście składał, i którymi wywołał zaufanie drugiej strony, na czym druga strona zasadnie oparła swoje postępowanie ${ }^{13}$.

Pojęcie dobrej wiary w sensie obiektywnym ${ }^{14}$ - powszechnie używane w zagranicznych porządkach prawnych - zostało w Polsce powojennej zastapione pojęciem zasad współżycia społecznego, które uczyniono jednym z kryteriów wykonania zobowiązania (art. 354 k.c.), a po 1990 roku także granicą wytyczającą swobodę kontraktową stron (art. $353^{1}$ k.c.) ${ }^{15}$. Klauzula dobrej wiary pomaga

6. Państwa członkowskie zapewniaja, aby dystrybutorzy ubezpieczeń, świadcząc dystrybucję ubezpieczeń, zawsze postępowali uczciwie, rzetelnie i profesjonalnie, zgodnie z najlepiej pojętym interesem swoich klientów.

7. Zob. R. Zimmermann, The civil law in European codes, [w:] Regional private laws and codification in Europe, [eds.] H. McQueen, A. Vaquer, S. Espiau, Cambridge University Press, Cambridge 2007, s. 58.

8. "Nie wolno występować przeciwko temu, co wynika z własnych czynów”.

9. Zob. A. Szpunar, Nadużycie prawa podmiotowego, PAU, Kraków 1947, s. 63.

10. Są one przedmiotem obszernych opracowań z zakresu różnych dogmatyk oraz teorii praw. Zamiast wielu zob. L. Leszczyński, Stosowanie klauzul generalnych odsyłajacych, Wolters Kluwer, Kraków 2001; Z. Radwański, M. Zieliński, [w:] System prawa prywatnego: Prawo cywilne - część ogólna, [red.] M. Safjan, CH Beck, Warszawa 2007, s. 336.

11. Zob. A. Szpunar, op. cit., s. 6?.

12. R. Longchamps de Berier, Zobowiqzania (reprint), Księgarnia Akademicka, Poznań 1999, s. 141.

13. W kontekście wykonywania praw wynikających z umowy zob. R. Zimmermann, S. Whittaker, Good faith in European Contract law, Cambridge University Press, Cambridge 2008, s. 521-522.

14. Tj. w znaczeniu oderwanym od przyjmowanego w przepisach k.c., np. art. 3, 231 k.c.

15. Wyrok TK z 17 października 2000 r. SK 5/99, 0TK $>/ 2000$, s. 254 - zasady współżycia społecznego powinny być oderwane od ich socjalistycznej konotacji i być rozumiane tak, jak zasada dobrej wiary. Zob. Z. Radwański, M. Zieliński, op. cit., s. 336-338. 
sądowi nadać szczegółową treść ogólnemu obowiązkowi kooperacji stron, który z natury rzeczy musi być określony elastycznie ${ }^{16}$. Dobra wiara w tym znaczeniu powoli zajmuje coraz szersze pole w europejskim prawie umów, została wprowadzona także do zasad zharmonizowanego prawa umów $^{17}$. W unijnym prawie zobowiązań wprowadzenie obowiązku działania w dobrej wierze nastąpiło w dyrektywie nr 86/653/EWG z 18 grudnia 1986 roku w sprawie koordynacji ustawodawstw Państw Członkowskich odnoszących się do przedstawicieli handlowych działających na własny rachunek ${ }^{18}$ i odzwierciedlało znany w systemach common law obowiązek obustronnej lojalności, charakterystyczny dla umów szczególnego zaufania.

Obok klauzul generalnych istnieją także inne zwroty niedookreślone i kryteria ogólne oceny postępowania dłużnika na etapach zawierania umowy, kształtowania jej treści oraz wykonywania.

\section{Uczciwość i rzetelność oraz klauzula dobrych obyczajów}

Wskazane klauzule zostaną omówione łącznie, ponieważ w istocie rzeczy chronią te same, a w każdym razie bardzo zbliżone wartości etyczne. Ponadto językowe znaczenie pojęcia rzetelności pokrywa się z terminem „uczciwość” ( rzetelne jest działanie sumienne, uczciwe, solidne ${ }^{19}$ ). Treści obu kryteriów nie trzeba bliżej wyjaśniać. Każdy, kto posiada choćby minimalne rozeznanie o życiu społecznym i panujących w nim zasadach, wie, co to oznacza postępować uczciwie czy rzetelnie. Jednak żadne ze znaczeń przypisywane pojęciu rzetelności w polskim języku pozaprawnym nie obejmuje sprawiedliwości czy też bezstronności, które spotykamy w innych wersjach językowych art. 17 IDD. Czy w takim razie można uznać, że ustawodawca polski pominałł kryterium bezstronności / sprawiedliwości działania dystrybutora ubezpieczeń? Jest to pytanie istotne w kontekście różnych kategorii pośredników funkcjonujących od lat na polskim rynku ubezpieczeń, a obecnie włączonych do wspólnej kategorii ustawowej dystrybutora (art. 3 pkt 8 u.d.u.). Sposób ich powiązania z zakładem ubezpieczeń wpływa na ocenę bezstronności. Prima facie wydaje się, że kryterium bezstronności mieści się zarówno w nakazie uczciwości postępowania, jak i w kryterium staranności (zob. uwagi poniżej).

W znaczeniu prawnym „uczciwość i rzetelność wobec kogoś” to desygnat pojęcia lojalności²0. W doktrynie polskiej i zagranicznej trafnie identyfikuje się różne stopnie intensywności obowiązku lojalności. I tak, podstawowy sens tego obowiązku określa się jako nieutrudnianie wykonywania powinności umownych dłużnika oraz obowiązek koniecznego współdziałania stron. Ten sposób rozumienia lojalności kontrahentów wynika z art. 354 k.c. (scil. z zasad współżycia społecznego),

16. Zob. R. Schulze, F. Zoll, European Contract Law, CH Beck, Warszawa 2018, s. 85.

17. Zob. Art. III - 1:103 Draft Common Frame of Reference; zob. Principles, definitions, and model rules in European private law: Draft Common Frame of Reference (DCFR), [eds.] C. von Bar, E. Clive, H. Schulte-Nölke, Sellier, Munich 2009.

18. Dz.Urz. L z 1986 r., Nr 382, s. 1 ?.

19. Słownik języka polskiego pod red. W. Doroszewskiego, PWN, Warszawa 1997 podaje trzy znaczenia słowa rzetelny: 1. «wypełniający należycie swe obowiązki» 2. «taki, jaki powinien być, odpowiadający wymaganiom» 3. «zgodny z prawda, wiarygodny».

20. Drugie znaczenie lojalnego postępowania to „postępowanie zgodnie z nakazami władz, zgodnie z obowiazujacym prawem". Wielki słownik poprawnej polszczyzny PWN, [red.] A. Markowski, PWN, Warszawa 2010 podaje oba znaczenia słowa lojalny, s. 485. 
a zatem jest elementem każdego zobowiązania ${ }^{21}$. Obowiązek lojalności może także stanowić element natury określonego rodzaju stosunku zobowiązaniowego. Wówczas polega on na czynieniu czegoś więcej niż nieutrudnianie czy współdziałanie i obejmuje pozytywne dbanie o interes kontrahenta. Taki wyższy stopień lojalności może wynikać z ustawy badź umowy stron, zwłaszcza w stosunkach trwałych, opartych na współdziałaniu stron lub na pośrednictwie ${ }^{22}$. Jest on charakterystycznym elementem umów szczególnego zaufania bądź najwyższej dobrej wiary (contractus uberrimae fidei]. Do tej kategorii należą m.in. umowa agencyjna, umowa ubezpieczenia, umowa brokerska, a także ogólnie umowy o pośrednictwo (por. art. 517 kodeksu zobowiązań). Najwyższy stopień obowiązku lojalnego działania występuje w stosunkach powierniczych, w których oczekuje się dbania o interes kontrahenta bardziej niż o interes własny.

Szczególne zaufanie między brokerem a klientem wynika już z samej natury umowy brokerskiej oraz pozycji zawodowej brokera, natomiast między ubezpieczycielem a klientem - z natury umowy ubezpieczenia lub umowy gwarancji ubezpieczeniowej oraz roli społecznej zakładu, który należy, obok banków, do instytucji finansowych najwyższego zaufania. Lojalność wyższego stopnia uzasadnia ponadto istotna dysproporcja (między stronami) możliwości ustalenia ważnych do współpracy kontraktowej faktów i informacji, a także okoliczność, że prawo nakłada na dana stronę obowiązki informacyjne dotyczące treści zobowiązania zabezpieczone sankcjami. Z charakteru kontraktów uberrimae fidei płynie zatem nakaz dochowania rzetelności i uczciwości w postępowaniu każdego brokera oraz pracownika zakładu ubezpieczeń przy dystrybucji ubezpieczeń. W tej kwestii art. $?$ u.d.u. in principio utrwala jedynie dotychczas obowiązujące zasady.

W odniesieniu do agenta natomiast kwestia obowiązku lojalności wygląda inaczej, gdyż agent wyłączny oraz multiagent wykonują działalność agencyjną na podstawie umowy agencyjnej zawartej z zakładem ubezpieczeń (art. 3 ust. 1 pkt 1 i pkt 2 u.d.u.), a zatem są zobowiązani do lojalności wobec reprezentowanego zakładu, o czym wprost mówi art. 760 k.c. ${ }^{23}$ Norma ta wyraża to, co implementowana przez nią Dyrektywa 86/653/EWG określa jako klauzulę dobrej wiary (good faith). Określenie standardów współpracy kontraktowej stron umowy agencyjnej nie przeszkadza oczywiście określeniu przez ustawodawcę również standardów postępowania agenta wobec klienta - potencjalnej strony umowy z reprezentowanym zakładem. Szczególna lojalność agenta wobec zakładu ubezpieczeń nie umniejsza bowiem stopnia rzetelności i uczciwości wobec klienta; kryteria te w żaden sposób nie pozostają z sobą w sprzeczności. Uwaga ta dotyczy zarówno agenta wyłącznego, jak i multiagenta, który w porównaniu z agentem wyłącznym jest w relacji lojalności wobec kilku reprezentowanych zakładów ubezpieczeń. W praktyce, multiagent,

21. Zob. P. Machnikowski, Prawne instrumenty ochrony zaufania przy zawieraniu umowy, Wydawnictwo Uniwersytetu Wrocławskiego, Wrocław 2010, s. 103 i nast. Zob. wyrok SN z 12 grudnia 1980 r., III CRN 275/80, OSN nr 9/2981, poz. 172.

22. Zob. np. A. Burzak, Umowa o pośrednictwo (I), „Przegląd Prawa Handlowego” 1992, nr 2, s. 19; M. Romanowski, Umowa o pośrednictwo w obrocie giełdowym (zlecenie maklerskie), CH Beck, Warszawa 2000, s. 164; J. Pokrzywniak, Obowiqzek lojalności jako element stosunku obligacyjnego, „Monitor Prawniczy” 2003, nr 19, passim.

23. Art. 760 k.c. implementuje art. 3 ust. 1 (odnoszący się do obowiązków agenta) i art. 4 ust. 1 (co do obowiązków dającego zlecenie) dyrektywy Rady nr 86/653/EWG. TSUE w wyr. z 17.5.2017 r., C-48/16, ERG0 Poist'ovňa, a.s. v. Alžbeta Barlíkova orzekł, że celem dyrektywy 86/653/EWG jest w szczególności zapewnienie ochrony interesów przedstawiciela handlowego (agenta), , przy czym - w myśl tej dyrektywy - przedstawiciel handlowy i zleceniodawca muszą postępować wobec siebie lojalnie oraz zgodnie z zasadą dobrej wiary". 
proponując klientowi kilka alternatywnych umów, może kierować się subiektywnymi motywami (chęcią osiągnięcia wyższej prowizjii ${ }^{24}$ ), a w konsekwencji de facto faworyzować jednego ubezpieczyciela ${ }^{25}$. Powyższą wykładnię wzmacnia treść art. 18 u.d.u. in fine proklamującego obowiązek agenta działania z zachowaniem dobrych obyczajów. Ustawodawca nie pozostawił zatem wạtpliwości, że programowa lojalność agenta wobec zlecającego nie zwalnia agenta od prowadzenia działalności z zachowaniem dobrych obyczajów.

Tytułem przykładu: sprzeczne z dobrymi obyczajami i wymogiem rzetelności będzie nieodpowiednie, niewystarczające, zbyt powierzchowne informowanie o ukrytych kosztach, opłatach i ryzykach związanych z daną umową, wykorzystanie niewiedzy klienta w zakresie ryzyk, których ochrony poszukuje ${ }^{26}$, oferowanie pokrycia ryzyk, które w danej sytuacji nie występują, oferowanie polis osobom, co do których było wiadomo, że nie byłyby uprawnione do uzyskania odszkodowania, uwypuklanie pozytywnych cech danego rodzaju polisy przy zminimalizowaniu cech negatywnych [np. klauzul wyłaczających odpowiedzialność). W stosunku do brokera oraz dystrybutora - zakładu ubezpieczeń - do powyższych zachowań nieuczciwych można dodać tworzenie i oferowanie umów nieodpowiednich dla klientów, w szczególności nieuwzgledniajacych ich uwarunkowań behawioralnych i poziomu wiedzy finansowej, czy też konstruowanie ubezpieczenia w sposób nieefektywny dla klienta ( $\mathrm{np}$. zawierającego wyłączenia w znacznym stopniu ograniczające prawdopodobieństwo wypłaty odszkodowania w przypadku choroby lub niezdolności do pracy]2?.

Wymagania rzetelności w stosunku do brokerów zawsze były wyższe niż w stosunku do agentów. Można zaryzykować tezę, że w u.d.u. zostały podniesione niemal do poziomu charakterystycznego dla stosunków powierniczych. Świadczą o tym przede wszystkim przepisy u.d.u. dotyczące obowiązku zapobiegania konfliktom interesów w drodze działań administracyjnych, organizacyjnych oraz informacyjnych. Każdy pośrednik ubezpieczeniowy oraz zakład ubezpieczeń (jako dystrybutor] jest zobowiązany ujawnić klientowi ogólny charakter lub źródła konfliktu interesów, jakie moga powstać między pośrednikami i zakładami, osobami ich kontrolującymi, pracownikami, a także między klientami - odpowiednio wcześnie przed zawarciem umowy ubezpieczenia (art. 15 u.d.u.). Wynika stąd, że interes (ekonomiczny) pośrednika ma ustępować przed interesem klienta, który nie może zostać naruszony. A to już nie jest zwykła, lecz szczególnie wysoka lojalność pośrednika, zbliżająca się do lojalności powiernika ${ }^{28}$. Na świecie przykładem ustawowego

24. Zob. w kwestii zróżnicowania prowizji dla multiagentów wyważone i pragmatyczne stanowisko J. Pokrzywniaka, Multiagent w ustawie o dystrybucji ubezpieczeń, „Wiadomości Ubezpieczeniowe” 2019, nr 2, s. 18-19 i 21-22 (https://doi.org/10.33995/wu2019.2.2 [dostęp: 2.11.2019]).

25. Inną kwestia, pozostająca poza zakresem niniejszych rozważań, jest skuteczność postanowień umowy agencyjnej z multiagentem, które przewidują określone zasady faworyzowania zakładu dającego zlecenie.

26. Zob. uchwałę SN z 29 czerwca 2007 r., III CZP 62/07, 0SNC nr 7-8/2008, poz. 87 (na tle ogólnych warunków ubezpieczenia zaopatrzenia dzieci SN stwierdził m.in. „Działanie odbiegające in minus od przyjętych standardów postępowania przez ukształtowanie stosunku zobowiązaniowego w stanie niewiedzy klienta co do istotnych elementów tego stosunku pozostaje w sprzeczności z dobrymi obyczajami”).

27. Zob. K. Alexander, Marketing, Sale and Distribution. Mis-selling of Financial Products. A study for the European Parliament, European Union, 2018, s. 912 (http://www.europarl.europa.eu/RegData/etudes/STUD/2018/618996/ IPOL_STU(2018)618996_EN.pdf dostęp: 7.10.2019]).

28. Tak słusznie P. Machnikowski, op. cit., s. 106. 
Wpływ klauzul generalnych na proces zawierania umowy ubezpieczenia...

uregulowania obowiązku powierniczego (fiduciary duty) są regulacje dotyczące brokerów na pierwotnym i wtórnym rynku ubezpieczeń na życie w Stanach Zjednoczonych ${ }^{29}$.

Przypadki naruszeń zasad uczciwości i rzetelności w wykonywaniu zawodu brokera zazwyczaj wiążą się ze sposobem (systemem) wynagrodzenia. Przykładem podważenia systemu prowizji warunkowych jest kazus ze Stanów Zjednoczonych ${ }^{30}$. W 2004 roku Prokurator stanowy stanu Nowy Jork podważył system premii, które ubezpieczyciele wypłacaja brokerom i niezależnym agentom za sprowadzenie do ubezpieczyciela szczególnie dużej liczby dochodowych klientów. Pracownicy dużej firmy brokerskiej Marsh\&McClellan domagali się celowo zawyżonych notowań cen od niektórych ubezpieczycieli. To manipulowanie ofertami pozwalało brokerom kierować klientów do konkretnych ubezpieczycieli, albowiem klienci byli fałszywie przekonywani, że rekomendowany ubezpieczyciel „zwyciężył” w konkurencji ofert cenowych. Jedyną korzyścią z tej nieuczciwej praktyki było otrzymanie dodatkowych prowizji kwotowych. Śledztwo doprowadziło do postawienia zarzutów sześciu największym podmiotom z branży ubezpieczeniowej oraz członkom ich zarządów, zaś sankcje sięgnęły około 3 mld dolarów (w ramach restytucji i kar) ${ }^{31}$.

\section{Profesjonalizm i staranność dystrybutora}

Klauzula postępowania profesjonalnego (profesjonalizmu) nawiązuje wprost do kryterium należytej staranności i można ją wywieść z art. 355 k.c. Przy ocenie, czy pośrednik wykonał zobowiązanie z należytą starannością, znaczenie będzie miało dochowanie uczciwości i rzetelności w postępowaniu. Na wzorzec staranności pośrednika ubezpieczeniowego (jego „profesjonalizmu” w ujęciu u.d.u.) składa się więc jego lojalność. Zastanawiające jest, że u.d.u. poza wzmianką o profesjonalizmie w art. ?, dość niespodziewanie dodatkowo odwołuje się do obowiązku staranności agenta w art. 18, odsyłając w nim wprost do art. 355 k.c. Jednocześnie brak podobnego przepisu, który dotyczyłby brokera lub innego dystrybutora (zakładu ubezpieczeń). Być może wiąże się to z faktem, że profesjonalizm, podobnie jak najwyższe zaufanie, są wpisane w naturę i historię zawodu brokera ubezpieczeniowego ${ }^{32}$.

W myśl art. 355 § 2 k.c. należyta staranność dłużnika w zakresie prowadzonej przez niego działalności gospodarczej określa się przy uwzględnieniu zawodowego charakteru tej działalności. Należyta staranność określona w art. 355 k.c. to pojęcie o ustalonej w doktrynie i praktyce orzeczniczej wykładni. Poziom staranności w sensie abstrakcyjnym wyznaczaja przepisy, normy deontologiczne, zasady sztuki, dobre obyczaje i zasady współżycia społecznego, precyzuje zaś - orzecznictwo. Staranność dotyczy zarówno procesu zawierania umowy, jak i jej wykonywania, w tym m.in. informowania klienta o stanie spraw (np. stanie negocjacji).

29. Zob. M. Marszelewski, Broker jako pośrednik na wtórnym rynku ubezpieczeń na życie w Stanach Zjednoczonych, [w:] Dystrybucja usług ubezpieczeniowych. Wybrane zagadnienia prawne, [red.] B. Gnela, M. Szaraniec, DIFIN, Warszawa 2017, s. 319, 326, 327.

30. Zob. D. Schwarcz, Beyond Disclosure: The Case for Banning Contingent Commissions, „Yale Law \& Policy Review" 2007, Vol. 25, s. 290 i nast.

31. Wszczęto też podobne śledztwa w 20 innych stanach. Ibidem, s. 291.

32. Zob. E. Kowalewski, Makler ubezpieczeniowy - broker, TNOiK, Bydgoszcz 1991, s. 15 i nast. 
Współcześnie już sama specyfika umowy ubezpieczenia oraz umowy gwarancji ubezpieczeniowej implikuje konieczność szczególnej staranności i profesjonalizmu każdego pośrednika ubezpieczeniowego, a w szczególności brokera. Ubezpieczony otrzymuje bowiem jedynie obietnicę spełnienia przyszłego świadczenia przez ubezpieczyciela pod warunkiem wystapienia wypadku ubezpieczeniowego. Ponadto ryzyko ekonomiczne klienta przekracza znacznie wartość wynagrodzenia za usługę pośrednictwa, co widać zwłaszcza na przykładzie ubezpieczeń z elementem inwestycyjnym. Skoro jednak również agent ubezpieczeniowy (lub agent oferujący ubezpieczenia uzupełniajacce] musi być przedsiębiorca, to jasne jest, że wykonuje on działalność w sposób zawodowy w rozumieniu art. 355 § 2 k.c. A zatem art. 18 u.d.u. in principio jest superfluum ustawowym.

Wykonywanie każdej działalności w sposób zawodowy implikuje w świetle prawa cywilnego dwa podstawowe obowiązki: obowiązek kompetencji oraz obowiązek udzielenia informacji i wskazówek ${ }^{33}$.

Odnośnie do obowiązku kompetencji, każdy dystrybutor posiada (lub przynajmniej powinien posiadać] szczególną wiedzę na temat mechanizmu działania ubezpieczenia, ochrony ryzyka, pokrycia finansowego itp., której nie ma odbiorca usługi dystrybucyjnej. Najwyższego poziomu wiedzy wymaga się jednak od brokera ubezpieczeniowego jako fachowca w dziedzinie ubezpieczeń, zobowiązanego ponadto do doradztwa ${ }^{34}$. Niemniej wydaje się, że agenci i brokerzy zostali różnie potraktowani w u.d.u. Ustawodawca skoncentrował się bowiem na zapewnieniu wysokich kompetencji brokera, ustanawiając zasady ich weryfikacji i egzekwowania przez organy państwowe. Nie uchybia to ogólnemu obowiązkowi stałego podnoszenia kompetencji zawodowych, żadne bowiem dyplomy nie zastapią rzeczywistego znawstwa rynku ubezpieczeniowego, oferowanych rodzajów ubezpieczeń, wiedzy o sposobach zarządzania ryzykiem klienta oraz umiejętności niezbędnych do oceny (analizy) potrzeb klienta, a następnie do zaoferowania mu najlepiej dopasowanej umowy ubezpieczenia lub gwarancji ubezpieczeniowej, zgodnej z wymaganiami i potrzebami klienta w zakresie ochrony ubezpieczeniowej lub gwarancyjnej. Stąd ustawowy obowiązek stałego doskonalenia zawodowego jest wyrazem ogólnego obowiązku kompetencji (w odniesieniu do pracownika zakładu ubezpieczeń - zob. art. 12 u.d.u.).

Najszerzej uregulowany ustawowo i opisany w literaturze jest obowiązek informacji. Obowiązek informacyjny to obowiązek każdego przedsiębiorcy, mający charakter bardziej ogólny w prawie cywilnym. Jego celem jest niwelacja asymetrii informacyjnej w relacjach profesjonalista-profan ${ }^{35}$. Jest on bardzo istotny w procesie zawierania umowy ubezpieczenia, tym bardziej, że spoczywa na obu stronach przyszłej umowy ${ }^{36}$. Zakres tego obowiązku różni się w zależności od tego, czy umowę proponuje pośrednik zależny czy niezależny. Jeżeli chodzi o ubezpieczyciela i agenta ubezpieczeniowego, obowiązek dotyczy przede wszystkim informowania w sposób obiektywny, niewprowadzający w błąd i bezstronny o dostępnych rodzajach umów ubezpieczenia, zakresie ochrony itd. Natomiast obowiązek informacyjny brokera jest powiązany z obowiązkiem doradztwa (udzielenia rady), a więc jest silniejszy; obejmuje udzielenie wskazówek, konieczność zwró-

33. Zob. B. Lewaszkiewicz-Petrykowska, Uwagi o zawodowym obowiqzku udzielenia informacji, „Studia luridica” 1994, $\mathrm{nr}$ XXI, s. 4 ? i nast.

34. Zob. M. Serwach, Umowa brokerska, [w:] System prawa prywatnego. Tom 9: Prawo zobowiqzań - umowy nienazwane, [red.] W. Katner, CH Beck, Warszawa 2018, s. 929.

35. Zob. B. Lewaszkiewicz-Petrykowska, op. cit., s. 50-51.

36. Zob. P. Tereszkiewicz, Obowiqzki informacyjne w umowach o usługi finansowe, Wolters Kluwer, Warszawa 2015 (zwłaszcza rozdział II passim). 
cenia uwagi lub nawet ostrzeżenia (np. o ryzyku związanym z „uczciwym” ratingiem finansowym ubezpieczyciela, o braku stabilności finansowej zakładu, o słabej reputacji w zakresie zarządzania roszczeniami itp.]. W nowym reżimie prawnym dystrybucji ubezpieczeń kwestia wykonania przez dystrybutora tzw. obowiązku eksploracyjnego będzie musiała być oceniona w świetle danych, które otrzymał w celu ustalenia potrzeb klienta, a także danych, których nie pozyskał, ale mógł nimi dysponować, mając na uwadze wymagania określonej umowy ubezpieczeniowej. Należy też przypomnieć, że z natury umowy brokerskiej jako kontraktu uberrimae fidei wypływa wzajemny obowiązek informacyjny, a zatem również podmiot poszukujący ochrony ubezpieczeniowej ma obowiazzek udzielenia brokerowi informacji, niezbędnych do zaproponowania mu odpowiednich do jego potrzeb warunków umowy ubezpieczenia i uwzględniających np. wprowadzanie tzw. klauzul brokerskich, a z drugiej strony - pozwalających brokerowi na oszacowanie ryzyka37.

Do zobowiązania staranności dystrybutora u.d.u. włączyła obowiązek zaproponowania umowy ubezpieczenia lub umowy gwarancji ubezpieczeniowej zgodnej z wymaganiami i potrzebami klienta (art. 8 ust 3). Niewątpliwie wprowadzenie tego obowiązku wywiera bezpośredni wpływ na zakres obowiązku pozyskania odpowiednich (w stosunku do poszukiwanej ochrony oraz rodzajów ryzyka] faktów i informacji należących do sfery osobistej klienta. Z drugiej strony, zdolność pośrednika do zidentyfikowania słabych stron ubezpieczonego i zaoferowania konkretnych metod zmniejszania ryzyka jest istotnie zagrożona, gdy ubezpieczający zataja pełne i dokładne informacje o ryzyku.

Należy wreszcie podkreślić, że staranność zawodowa dystrybutora ubezpieczeń oznacza również obowiązek zachowania wysokiego poziomu etyki. W tym sensie obowiązek należytej staranności nawiązuje do uczciwości postępowania dłużnika (lojalności kontraktowej) i bezstronności udzielanych porad i wskazówek. Zatem w kryterium uczciwości i profesjonalizmu mieści się obowiązek działania bezstronnego w rozumieniu art. 17 IDD. Bezstronność postępowania dystrybutora in concreto należy oceniać z uwzględnieniem całokształtu okoliczności istniejących w chwili zawierania umowy. Nawiązując do przykładu działania multiagenta, można zauważyć, że z punktu widzenia klienta, jeżeli multiagent działa pod szyldem tzw. placówki partnerskiej określonego zakładu ubezpieczeń, to przekaz, że ten właśnie zakład jest traktowany jako „ubezpieczyciel pierwszego wyboru" wydaje się bardziej transparentny. Niezależnie od tego, klient zazwyczaj nie wie o ograniczeniach nakładanych w umowach agencyjnych na multiagenta, np. takich, że oferty innych zakładów mogą być prezentowane klientowi dopiero wówczas, gdy brak odpowiedniej oferty w zakładzie „pierwszego wyboru” lub gdy proponowana umowa nie spełnia potrzeb i wymagań klienta.

\section{Działanie w „najlepszym interesie klienta”}

Najwięcej wạtpliwości doktrynalnych budzi klauzula tzw. najlepszego interesu klienta ${ }^{38}$. Współczesne przepisy unijne i krajowe dotyczące świadczenia usług finansowych, zwłaszcza inwestycyjnych i ubezpieczeniowych, wprowadzają najwyższy stopień ochrony interesu klienta. Obowiązek dzia-

37. Tak trafnie M. Serwach, Broker jako strona umowy brokerskiej, [w:] Broker w świetle prawa i praktyki ubezpieczeniowej, [red.] M. Serwach, Wydawnictwo Uniwersytetu Łódzkiego, Łódź 2012, s. 92.

38. Zob. K. Malinowska, Najlepszy interes klienta - rozważania na tle regulacji dystrybucji ubezpieczeń, [w:] Dystrybucja usług ubezpieczeniowych..., s. 108 i nast. 
łania zgodnie z najlepiej pojętym interesem klienta stanowi nie tylko zasadę ogólną działania firm inwestycyjnych w świetle MIFID I ${ }^{39}$, oraz MIFID II0 ${ }^{40}$ lecz obecnie można go również uznać za zasadę działania dystrybutorów ubezpieczeń wyrażoną w art. 19 ust. 2 IDD i art. 7 ust. 2 u.d.u. Okoliczność, że klient może nie być stroną stosunku ubezpieczeniowego z dystrybutorem (co ma miejsce w przypadku agentów i multiagentów), traci na znaczeniu. Celem tej klauzuli jest próba zaradzenia inherentnej asymetrii informacyjnej w stosunkach ubezpieczeniowych oraz zapewnienie wzmożonej ochrony w związku z przekazywaniem przez klientów wielu wrażliwych danych osobistych dotyczących ryzyk, co do których poszukują oni ochrony.

Obowiazzek działania w najlepszym interesie klienta realizowany jest m.in. za pomoca nakazu, aby proponowana umowa ubezpieczenia lub gwarancji ubezpieczeniowej była zgodna z wymaganiami i potrzebami klienta, co musi być poprzedzone właściwym określeniem tych potrzeb i wymagań. Obowiązek ten jest rozwijany także w przepisach dotyczących: wynagrodzenia dystrybutorów ubezpieczeń, obowiązku informacyjnego, publikacji reklam, a także proponowanej strategii inwestycyjnej, co obejmuje również informacje o podmiotach realizujących zlecenia, powinność ostrzeżenia o ryzyku, wreszcie - koszty i opłaty.

Szczególne znaczenie klauzuli widać w kontekście systemu wynagradzania dystrybutorów ubezpieczeń na życie z elementem inwestycyjnym. Ustawodawca wprowadza m.in. kryteria „braku szkodliwego wpływu" opłaty lub korzyści przyjmowanej przez dystrybutora na jakość jego usługi świadczonej na rzecz klienta, a także brak naruszenia obowiązku uczciwego, rzetelnego i profesjonalnego działania.

Nakaz działania w najlepszym interesie klienta stanowi kolejny przejaw obowiązku lojalności ${ }^{41}$. Powinność działania w interesie przyrzekającego wynagrodzenie i zabieganie o jego interesy stanowi bowiem typową i pierwotną eksplikację obowiązk lojalności. 0 ile jednak jest dość jasne, że szczególna lojalność agenta wobec zakładu ubezpieczeń nie umniejsza stopnia rzetelności i uczciwości wobec klienta, to już relacja między zobowiązaniem agenta wobec zakładu ubezpieczeń dbania o jego interesy a obowiązkiem działania w najlepszym interesie klienta budzi wạtpliwości, co podniesiono na etapie prac legislacyjnych nad wdrażaniem dyrektywy IDD ${ }^{42}$. Niewatpliwe istnieje problem niedopasowania definicji klienta ${ }^{43}$ do charakteru pośrednictwa agenta. W świetle u.d.u. klientem jest osoba poszukująca ochrony ubezpieczeniowej, ubezpieczajacy lub ubezpieczony - w przypadku umów ubezpieczenia, a także zleceniodawca gwarancji ubezpieczeniowej

39. Dyrektywa PE i Rady 2004/39/WE z 21 kwietnia 2004 r. w sprawie rynków instrumentów finansowych, zmieniająca dyrektywę Rady 85/611/EWG i 93/6/EWG i dyrektywę 2000/12/WE PE i Rady oraz uchylająca dyrektywę Rady 93/22/EWG, Dz. Urz. UE L 145 z 30 kwietnia 2004 r., s. 263.

40. Dyrektywa PE i Rady 2014/65/UE z 15 maja 2014 r. w sprawie rynków instrumentów finansowych oraz zmieniająca dyrektywę 2002/92/WE i dyrektywę 2011/61/UE, Dz. U. UE L 2014.173.349 z późn. zm.

41. Zob. M. Barański, Obowiqzki oraz odpowiedzialność kontraktowa stron umowy o pośrednictwo zwykłe, [w:] Prawo prywatne wobec wyzwań współczesności. Księga pamiqtkowa dedykowana Profesorowi Leszkowi Ogiegle, [red.] M. Fras, P. Ślęzak, CH Beck, Warszawa 2017, s. 4 i nast.

42. Zob. M. Orlicki, Aksjologia dystrybucji ubezpieczeń - kryteria uznawania działań dystrybutora za zgodne z prawem i etyczne, [w:] Dystrybucja usług ubezpieczeniowych ..., s. 24.

43. Zob. B. Gnela, Pojęcie klienta w ustawie o dystrybucji ubezpieczeń na tle wybranych sposobów określania podmiotów słabszych rynku finansowego, [w: 0 dobre prawo dla ubezpieczeń: księga jubileuszowa Profesora Eugeniusza Kowalewskiego, [red.] E. Bagińska, W.W. Mogilski, M. Wałachowska, TNOiK, Toruń 2019, s. 121, 132. 
- w przypadku umów gwarancji ubezpieczeniowej. Z podstawowej różnicy między pośrednictwem agenta i brokera wynika, że to broker powinien najintensywniej dbać o interesy podmiotu szukajacego ochrony ubezpieczeniowej (działa bowiem w jego imieniu lub na jego rzecz) i jemu winien jest najwyższą lojalność ${ }^{4}$. Natomiast agent, który działa dla zakładu ubezpieczeń, dba przede wszystkim o interes swojego kontrahenta. Nakazanie agentowi i multiagentowi działania w najlepszym interesie klienta usługi ubezpieczeniowej jest zatem nowością normatywna. Jest to bowiem obowiązek znacznie szerszy niż wynikałoby to z należytej staranności zawodowej, uczciwości i rzetelności pośrednika zależnego i niezobowiązanego do doradztwa. Co do zasady, gdyby nie art. $?$ u.d.u., ani agent, ani multiagent nie mieliby prawnego obowiązku działania w najlepszym interesie klienta; obowiązku takiego nie da się wyprowadzić z zasady dobrej wiary.

Nie można jednak pomijać faktu, że również broker de facto działa w ogólnym interesie ubezpieczyciela, skoro przysparza mu klientów i związany jest tzw. stosunkiem prowizyjnym (gdy kurtaż płacony jest przez ubezpieczyciela). W praktyce brokerzy obsługują bardziej wyrafinowanych klientów (zazwyczaj podmioty gospodarcze), w większym stopniu świadomych ryzyk, których pokrycia poszukują, natomiast agenci - tych mniej wyrafinowanych, tzw. zwykłych konsumentów ubezpieczeniowych. Sens klauzuli działania w najlepszym interesie klienta, a zarazem istota zmiany normatywnej, leży więc w rozszerzeniu zakresu obowiązku agenta i multiagenta wobec klientów usługi ubezpieczeniowej.

\section{Zgodność proponowanej umowy z wymaganiami i potrzebami klienta}

Powyższe uwagi pokazują inherentne powiązanie nakazu „zgodności proponowanej umowy z wymaganiami i potrzebami klienta" z kryteriami uczciwości i staranności oraz nakazem postępowania zgodnie z najlepiej pojętym interesem klienta. Propozycja adekwatnej ochrony jest bowiem rezultatem postępowania dystrybutora w sposób uczciwy, rzetelny, profesjonalny i w najlepszym interesie klienta na etapie badania i analizy jego potrzeb i wymagań. Można zastanawiać się, czy norma ta, o charakterze nakazowym, ma charakter nowej (lub innej) klauzuli generalnej.

W mojej ocenie reguła stanowiąca, że „każda proponowana umowa musi być zgodna z wymaganiami i potrzebami klienta w zakresie ubezpieczenia”, nie jest klauzula generalną w rozumieniu prawa cywilnego. Co więcej, nie czyni z agentów i multiagentów doradców klienta na podobieństwo brokera. W świetle IDD nakaz zapewnienia zgodności proponowanej umowy z wymaganiami i potrzebami klienta stanowi element poprawnego (i pożądanego przez legislatora europejskiego) procesu doradzania i oferowania klientowi adekwatnej ochrony ubezpieczeniowej lub gwarancyjnej ${ }^{45}$. Z punktu widzenia prawa europejskiego nakaz ten ma zapobiegać nieuczciwym praktykom w sektorze ubezpieczeń. Nie jest to rozwiązanie nowe w regulacji ubezpieczeniowej, występuje bowiem w węższym zakresie w art. 21 ustawy o działalności ubezpieczeniowej i reasekuracyjnej ${ }^{46}$

44. Zob. szerzej M. Serwach, Umowa brokerska..., s. 929 i nast.; B. Kucharski, Broker jako pośrednik handlowy, [w:] Broker w świetle prawa..., s. 55 i nast.

45. Zob. szerzej M. Szaraniec, Przyszły model pośrednictwa ubezpieczeniowego w Polsce w zakresie świadczenia usługi doradztwa - propozycje na tle dyrektywy w sprawie dystrybucji ubezpieczeń (IDD), „Prawo Asekuracyjne" 2017, nr 2, s. 36 i nast.

46. Dz. U. 2019, poz. 381. 
- w odniesieniu do ubezpieczeń na życie z ubezpieczeniowym funduszem kapitałowym, a jego naruszenie stanowi nieuczciwą praktykę naruszającą zbiorowe interesy konsumentów ${ }^{4 ?}$.

W odniesieniu do aspektu doradztwa należy dodać, że zgodnie z art. 20 ust 3 IDD w przypadku świadczenia doradztwa przed zawarciem każdej konkretnej umowy dystrybutor ubezpieczeń udziela klientowi zindywidualizowanej rekomendacji, wyjaśniając, dlaczego dany produkt najlepiej spełnia wymagania i potrzeby klienta. Obowiązek ten spoczywa więc na brokerze. U.d.u. doprecyzowała przepisy o sposobie wydania indywidualnej rekomendacji, tzw. rekomendacji brokerskiej (tj. „porady, w oparciu o rzetelną analizę dostępnych na rynku produktów ubezpieczeniowych w liczbie wystarczającej do opracowania rekomendacji najwłaściwszej umowy"] oraz obowiązku wyjaśnienia podstaw, na których opiera się rekomendacja, przy uwzględnieniu złożoności umowy ubezpieczenia lub umowy gwarancji ubezpieczeniowej oraz „rodzaju klienta” - zob. art. 32 ust. 1 pkt 4 u.d.u.J. Wprawdzie art. 4 ust. 1 pkt 1 u.d.u. zawiera w katalogu czynności dystrybucyjnych również „doradzanie” w procesie zamierzającym do zawarcia umów ubezpieczenia lub umów gwarancji ubezpieczeniowej, to jednak właściwa interpretacja obowiązków dystrybutora określonych w art. 8 ust. 1 u.d.u., zmierzających do zaproponowania umowy zgodnej z ustalonymi wymaganiami i potrzebami klienta, powinna uwzględniać naturę pośrednictwa wykonywanego przez danego dystrybutora. Trafnie stwierdza się w doktrynie, że ten zabieg legislacyjny nie uczynił z multiagenta (ani agenta) doradcy klienta na podobieństwo brokera ubezpieczeniowego ${ }^{48}$.

Wprawdzie ideą twórców IDD było „zapewnienie stosowania jednakowego poziomu ochrony konsumentów oraz korzystanie z porównywalnych standardów przez wszystkich konsumentów" przy założeniu wspierania równych warunków i konkurowania między pośrednikami oraz podkreśleniu korzyści płynących dla konsumentów z faktu istnienia różnych kanałów dystrybucji i pośredników współpracujących w różnych formach powiązania z zakładami ubezpieczeń (pkt 16 preambuły), to z drugiej strony, zamiarem dyrektywy nie było zniwelowanie różnic w rodzajach kanałów dystrybucji. W preambule (pkt. 17) wyraźnie nakazano ustawodawcom krajowym uwzględnienie odmiennej charakterystyki pośredników ubezpieczeniowych działających wyłącznie na rzecz jednego lub większej liczby zakładów ubezpieczeń (zależni pośrednicy ubezpieczeniowi) od pośredników niezależnych. Warunki stosowane do różnych rodzajów dystrybucji na poziomie prawa krajowego powinny być odpowiednie i proporcjonalne. Skoro jednak ustawodawca w zasadzie pominałł te różnice, nadając obecny kształt art. $?$ i 8 u.d.u., to odmienności wynikajacce z rodzaju pośrednictwa będą musiały być zauważone w ramach wykładni sądowej ${ }^{49}$.

W świetle powyższego uprawniony jest wniosek, że agent i mulitagent nie musi oceniać, która oferta jest najkorzystniejsza (najbardziej optymalna) dla poszukującego ochrony ubezpieczeniowej z punktu widzenia jego potrzeb i wymagań, lecz czy oferta umowy jest adekwatna, czyli zgodna ze starannie (z należytą starannościa)] i rzetelnie określonymi potrzebami prawidłowo poinformowanego klienta ${ }^{50}$.

47. Art. 24 ust. 2 pkt 4 ustawy z 16 lutego 2007 r. 0 ochronie konkurencji i konsumentów, Dz.U. 2019, poz. 369.

48. Zob. J. Pokrzywniak, Multiagent ..., s. 18-19.

49. Zob. Z. Długosz, Obowiqzek działania zgodnie z najlepiej pojętym interesem klientów w świetle pozycji prawnej agenta ubezpieczeniowego, [w:] 0 dobre prawo dla ubezpieczeń ..., s. 761.

50. Zob. szerzej Z. Długosz, Obowiqzek określenia wymagań i potrzeb klienta oraz jego granice, [w:] Dystrybucja usług ubezpieczeniowych ..., s. 138 i nast.; M. Orlicki, Aksjologia dystrybucji ..., s. 24. 
Znaczenie art. 8 ust. 3 u.d.u. polega zatem na rozszerzeniu zakresu podmiotowego obowiązku badania potrzeb klienta (nie tylko przez zakład ubezpieczeń, ale też przez dystrybutora), a także na wprowadzeniu jego stosowania wobec wszystkich rodzajów umów ubezpieczenia i umowy gwarancji ubezpieczeniowych (podlegających u.d.u.), a przez to na zapewnieniu prawidłowego procesu transakcyjnego w sektorze ubezpieczeń. Nie możemy tutaj mówić o wprowadzeniu klauzuli generalnej zmieniającej przepisy kodeksu cywilnego o umowie ubezpieczenia (art. 805 inast.). Co więcej, umowa, która nie jest zgodna z wymaganiami i potrzebami klienta w zakresie ochrony ubezpieczeniowej lub gwarancyjnej, nie staje się przez to nieważna (art. 58 k.c.).

\section{Podsumowanie}

U.d.u. wysławia podstawowe zasady wykonywania dystrybucji ubezpieczeń, które od lat powinny być stosowane przez pośredników ubezpieczeniowych: ich postępowanie musi być zgodne z kryteriami uczciwości i staranności, a proponowane umowy powinny wychodzić naprzeciw potrzebom klienta poszukującego ochrony w zakresie określonych ryzyk. Innymi słowy propozycja adekwatnej ochrony (która jest bytem odrębnym od rekomendacji brokerskiej) powinna być zawsze rezultatem postępowania dystrybutora w sposób uczciwy, rzetelny i profesjonalny.

Przedstawione wyżej klauzule stanowiące podstawę oceny zachowania dystrybutorów ubez- pieczeń oddziałują na etapie zawierania umowy ubezpieczenia, a przypadku niektórych dystrybutorów także na etapie jej wykonania. Ich desygnat zasadniczo pokrywa się z klauzulami dobrej wiary, dobrych obyczajów i należytej staranności dłużnika występujących w prawie zobowiązań. W kryterium uczciwości i profesjonalizmu mieści się również obowiązek działania bezstronnego w rozumieniu art. 17 IDD.

Mimo bardzo szczegółowego uregulowania przez u.d.u. procesu zawierania umowy ubezpieczenia (lub umowy gwarancji ubezpieczeniowej) oraz wynagrodzenia dystrybutorów, a także zapobiegania konfliktom interesów, klauzule generalne będą nadal spełniały istotna funkcję. Nie wszystko bowiem da się zapisać w przepisach. Nie zmienia to oceny, że treść niektórych z klauzul stanowi superfluum ustawowe (np. art. 18 u.d.u.).

Nieco dalej niż utrwalone zasady prawa zobowiązań idzie nakaz postępowania zgodnie z najlepiej pojętym interesem klienta. Należy uznać, że klauzula działania w najlepszym interesie klienta dokonała istotnej zmiany normatywnej, która polega na rozszerzeniu zakresu obowiązku agenta i multiagenta wobec klientów usługi ubezpieczeniowej.

Wreszcie, można skonstatować, że u.d.u. wprowadziła taką zmianę w sposobie zawierania umów przez brokerów oraz pracowników zakładów ubezpieczeń, której efektem jest podniesienie „obowiązku lojalności” do poziomu charakterystycznego dla stosunków powierniczych.

Na zakończenie należy podkreślić, że w świetle prawa polskiego za zachowania godzące w dobra wiarę (lojalność) oraz nieprofesjonalne i sprzeczne z u.d.u. broker będzie ponosić odpowiedzialność kontraktową wobec klienta (ubezpieczającego). Natomiast agenci moga ponosić odpowiedzialność wobec klienta jedynie ex delicto, gdyż nie łączy ich z klientem stosunek umowny. W świetle u.d.u. odpowiedzialność za agenta wyłącznego spoczywa bezpośrednio na reprezentowanym przez niego zakładzie ubezpieczeń, natomiast multiagent ponosi samodzielnie odpowiedzialność ex 
delicto (art. 20 ust. 1 i 2 ] ${ }^{51}$. Każdy z dystrybutorów może odpowiadać za naruszenie zbiorowych praw konsumentów.

\section{Wykaz źródeł}

Alexander K., Marketing, Sale and Distribution. Mis-selling of Financial Products. A study for the European Parliament, European Union, 2018, http://www.europarl.europa.eu/RegData/etudes/ STUD/2018/618996/IPOL_STU[2018]618996_EN.pdf [dostęp: 7.10.2019].

Barański M., Obowiq̨zki oraz odpowiedzialność kontraktowa stron umowy o pośrednictwo zwykłe, [w:] Prawo prywatne wobec wyzwań współczesności. Księga pamiqtkowa dedykowana Profesorowi Leszkowi Ogiegle, Fras M., Ślęzak P. [red.], CH Beck, Warszawa 2017.

Burzak A., Umowa o pośrednictwo (I), „Przegląd Prawa Handlowego” 1992, nr 2.

Długosz Z., Obowiqzek działania zgodnie z najlepiej pojętym interesem klientów w świetle pozycji prawnej agenta ubezpieczeniowego, [w: 0 dobre prawo dla ubezpieczeń: księga jubileuszowa Profesora Eugeniusza Kowalewskiego, Bagińska E., Mogilski W.W., Wałachowska M. [red.], TNOiK, Toruń 2019.

Długosz Z., Obowiqzek określenia wymagań i potrzeb klienta oraz jego granice, [w:] Dystrybucja usług ubezpieczeniowych. Wybrane zagadnienia prawne, Gnela B., Szaraniec M. [red.], DIFIN, Warszawa 2017.

Gnela B., Pojęcie klienta w ustawie o dystrybucji ubezpieczeń na tle wybranych sposobów określania podmiotów słabszych rynku finansowego, [w: ] 0 dobre prawo dla ubezpieczeń: księga jubileuszowa Profesora Eugeniusza Kowalewskiego, Bagińska E., Mogilski W.W., Wałachowska M. [red.], TNOiK, Toruń 2019.

Kowalewski E., Makler ubezpieczeniowy - broker, TNOiK, Bydgoszcz 1991.

Kucharski B., Broker jako pośrednik handlowy, [w: Broker w świetle prawa i praktyki ubezpieczeniowej, Serwach M. [red.], Wydawnictwo Uniwersytetu Łódzkiego, Łódź 2012.

Leszczyński L., Stosowanie klauzul generalnych odsyłajacych, Wolters Kluwer, Kraków 2001.

Lewaszkiewicz-Petrykowska B., Uwagi o zawodowym obowiqzku udzielenia informacji, „Studia luridica" 1994, nr XXI.

Longchamps de Berier R., Zobowiqzania (reprint), Księgarnia Akademicka, Poznań 1999.

Machnikowski P., Prawne instrumenty ochrony zaufania przy zawieraniu umowy, Wydawnictwo Uniwersytetu Wrocławskiego, Wrocław 2010.

Malinowska K., Najlepszy interes klienta - rozważania na tle regulacji o dystrybucji ubezpieczeń, [w: Dystrybucja usług ubezpieczeniowych. Wybrane zagadnienia prawne, Gnela B., Szaraniec M. [red.], DIFIN, Warszawa 2017.

Marszelewski M., Broker jako pośrednik na wtórnym rynku ubezpieczeń na życie w Stanach Zjednoczonych, [w:] Dystrybucja usług ubezpieczeniowych. Wybrane zagadnienia prawne, Gnela B., Szaraniec M. [red.], DIFIN, Warszawa 201 ?.

51. Dlatego też pokrycie tej odpowiedzialności gwarantuje obowiązkowe ubezpieczenie odpowiedzialności cywilnej z tytułu wykonywania czynności agencyjnych - zob. Rozporządzenie Ministra Finansów w sprawie obowiązkowego ubezpieczenia odpowiedzialności cywilnej z tytułu wykonywania czynności agencyjnych z dnia 18 maja 2018 r. (Dz. U. 2018, poz. 1007). 
Orlicki M., Aksjologia, dystrybucji ubezpieczeń - kryteria uznawania działań dystrybutora za zgodne z prawem i etyczne, [w:] Dystrybucja usług ubezpieczeniowych. Wybrane zagadnienia prawne, Gnela B., Szaraniec M. [red.], DIFIN, Warszawa 2017.

Pokrzywniak J., Obowiqzek lojalności jako element stosunku obligacyjnego, „Monitor Prawniczy” 2003, nr 19.

Pokrzywniak J., Multiagent w ustawie o dystrybucji ubezpieczeń, „Wiadomości Ubezpieczeniowe” 2019, nr 2 (https://doi.org/10.33995/wu2019.2.2 [dostęp: 2.11.2019]).

Principles, definitions, and model rules in European private law: Draft Common Frame of Reference [DCFR], Bar von C., Clive E., Schulte-Nölke H. [eds.], Sellier, Munchen 2009.

Radwański Z., Zieliński M., [w:] System prawa prywatnego: Prawo cywilne - część ogólna, Safjan M. [red.], CH Beck, Warszawa 2007.

Romanowski M., Umowa o pośrednictwo w obrocie giełdowym (zlecenie maklerskie), CH Beck, Warszawa 2000.

Schwarcz D., Beyond Disclosure: The Case for Banning Contingent Commissions, „Yale Law \& Policy Review" 2007, Vol. 25.

Serwach M., Broker jako strona umowy brokerskiej, [w:] Broker w świetle prawa i praktyki ubezpieczeniowej, Serwach M. [red.], Wydawnictwo Uniwersytetu Łódzkiego, Łódź 2012.

Serwach M., Umowa brokerska, [w:] System prawa prywatnego. Tom 9: Prawo zobowiqzań - umowy nienazwane, Katner W. [red.], CH Beck, Warszawa 2018.

Słownik języka polskiego pod red. W. Doroszewskiego, PWN, Warszawa 1997.

Schulze R., Zoll F., European Contract Law, Ch Beck, Warszawa 2018.

Szpunar A., Nadużycie prawa podmiotowego, PAU, Kraków 1947.

Tereszkiewicz P., Obowiqzki informacyjne w umowach o usługi finansowe, Wolters Kluwer, Warszawa 2015.

Szaraniec M., Przyszły model pośrednictwa ubezpieczeniowego w Polsce w zakresie świadczenia usługi doradztwa - propozycje na tle dyrektywy w sprawie dystrybucji ubezpieczeń (IDD), „Prawo Asekuracyjne” 2017, nr 2.

Wielki słownik poprawnej polszczyzny PWN, Markowski A. [red.], PWN, Warszawa 2010.

Zimmermann R., The civil law in European codes, [w:] Regional private laws and codification in Europe, McQueen H., Vaquer A., Espiau S. [eds.], Cambridge University Press, Cambridge 2007. Zimmermann R., Whittaker S., Good faith in European Contract law, Cambridge University Press, Cambridge 2008.

\section{Impact of the general clauses on the process of insurance contract conclusion in the light of the Act on Insurance Distribution}

The article discusses the principles of assessment of the conduct of insurance distributors envisaged by the new regime on distribution of insurance, implementing the IDD. The author investigates the content of the criteria of honesty, fairness, and professional diligence, as well as of the duty to act in the best interests of customers. She argues that the adequate proposal of insurance contract should always be the result of the distributor's conduct in a fair, reliable and professional manner. The abovementioned clauses essentially coincide with the clauses of good faith, good manners and due diligence of the debtor in contract law. Despite the detailed regulation of the process of concluding insurance 
contracts, distributors' remuneration and the conflict of interests, the general clauses will continue to play an important role. In particular, the clause of acting in the best interest of the customer has significantly extended the scope of the agent's and multi-agent's obligations towards their customers.

Key words: insurance distribution, multi-agent, insurance broker, the best interests of customers, general clauses, professional conduct.

PROF. DR HAB. EWA BAGIŃSKA - Katedra Prawa Cywilnego, Uniwersytet Gdański, członek Euro-pean Group on Tort Law.

e-mail: baginska@prawo.ug.edu.pl

nr orcid: 0000-0003-2950-8484 